Pamiętnik Literacki 2021, 3, s. 263-278

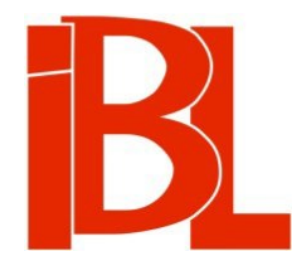

\title{
Norwid w Bibliotece Polskiej w Paryżu
}

Magdalena Abramczyk 
Pamiętnik Literacki CXII, 2021, z. 3, PL ISSN 0031-0514

DOI: $10.18318 / \mathrm{pl} .2021 .3 .15$

MAGDALENA ABRAMCZYK Instytut Badań Literackich PAN, Warszawa

\section{NORWID W BIBLIOTECE POLSKIEJ W PARYŻU}

W roku 1993 Józef Fert, prezentując swoje ówczesne rękopiśmienne odkrycia dotyczace Cypriana Norwida, stwierdzał: „Paryskie norwidiana to w zasadzie margines"1. I rzeczywiście, wydaje się, że szczególnie w przypadku takich twórców jak właśnie Norwid wszystko już zostało odnalezione i pieczołowicie omówione. Publikacja Adama Cedry z 2013 roku z powodzeniem posłuży tu jako przykład niezwykłych, choć często przypadkowych, odkryć, jakich wciąż można dokonać w archiwach $^{2}$. W swoim artykule autor zrelacjonował mianowicie odnalezienie we Francji aktu zgonu Norwida. Dokument odkrył mieszkający we Francji Andrzej Szczerba, który podzielił się tą informacją oraz zdjęciem archiwalium na Facebooku. Jak wiadomo, dotychczas najbardziej znany wśród badaczy był odpis owego aktu opublikowany przez Juliusza W. Gomulickiego. W świetle takich wydarzeń tym bardziej zaskakuje fakt, że do dziś w zakamarkach archiwów pozostają dokumenty czekające na swojego odkrywcę. Fakt ów zdumiewa jeszcze mocniej, gdy okazuje się, że znajdują się one w Bibliotece Polskiej w Paryżu, $\mathrm{z}$ którą poeta nigdy nie był silnie związany, ale w której wciąż opracowuje się kolejne, szerzej nieznane bloki dokumentów dotyczących życia polskiej emigracji.

Na przedstawione tu archiwalia natrafiono $\mathrm{w}$ trakcie działań $\mathrm{w}$ ramach projektu (nr 0514/NPRH/Hla/83/2015) w Bibliotece Polskiej w Paryżu, przy opracowywaniu spuścizny Alojzego Władysława Strzembosza. Pod tymczasowa sygnatura „AWS Komisja Opieki nad Grobami Polskimi w Paryżu” pośród wielu innych dokumentów znajdują się także te dotyczące śmierci poety, ale też lat późniejszych. Jak wskazuje nazwa akcesji, teczka obejmuje archiwalia związane $z$ działalnością Komisji Opieki nad Grobami Polskimi (obecnie: Towarzystwo Opieki nad Polskimi Zabytkami i Grobami Historycznymi we Francji), funkcjonującej nad Sekwaną od końca lat trzydziestych XIX wieku. Historia tej niezwykłej instytucji nierozerwalnie wiąże się z losem samotnych emigrantów, niemających własnych źródeł utrzymania, ale bardzo często weteranów polistopadowych zasłużonych dla ojczyzny, żyjących we Francji ${ }^{3}$. Głównym zadaniem komisji była organizacja pogrzebów oraz opieka nad polskimi grobami. Wiemy, że w latach pięćdziesiątych XIX wieku także Norwid zaangażował się w działania na rzecz instytucji, współpracując z Walentym Zwier-

1 J. Fer t, Nieznane Norwidiana w Bibliotece Polskiej w Paryżu. „Studia Norwidiana” t. 11 (1993), s. 125 .

A. C e d r o, Akt zgonu Norwida-dokument nieznany. Jw., t. 31 (2013).

3 Zob. A. N i e w ę gło w s k i, Towarzystwo Opieki nad Polskimi Zabytkami i Grobami Historycznymi we Francji. Historia. Na stronie: http://www.tombeauxpolonais.eu/content/historia (data dostępu: 22 III 2020). 
kowskim i Aleksandrem Jełowickim przy projektach pomników polskich grobów zbiorowych ${ }^{4}$. Jak się później okaże, również prochy poety ostatecznie zostaną powierzone opiece komisji.

W trzech koszulkach, podpisanych: C. K. Norwid: zaświadczenie z merostwa, ekshumacja 1888, Cyprian Norwid exhumation cimetière d'Ivry 18 listopada/novembre 1888 i Cyprian Norwid exhumation złożenie prochów cimetière du Sud (Montmorency) 27 novembre/listopada 1888, umieszczono kolejno: zaświadczenie o zgonie Norwida, z 24 V 1883, wydane przez merostwo XIII dzielnicy, rachunek za ekshumację na cmentarzu w Ivry, z 18 IV 1888, oraz rachunek za przeniesienie ciała na cmentarz w Montmorency, z 27 IX 1888. Do dokumentów dołączono także cztery rachunki: z 5 I 1889, 9 I 1891 i 4 V 1894 (za pochówek Juliusza Słowackiego na cmentarzu Montmartre) oraz jeden bez daty, za lata 1885-1889, od paryskiego przedsiębiorcy pogrzebowego, Gasparda Jacqueta, który sprawował opiekę nad polskimi grobami, a także bilet na loterię artystyczną organizowana przez Komisję Opieki.

Gdyby spróbować nadać pewną hierarchię ważności odnalezionym dokumentom, bez wattpienia na pierwszym miejscu znalazłoby się zaświadczenie z merostwa, następnie dwa rachunki z cmentarzy, a na końcu kalkulacje Jacqueta. Przyjrzyjmy się zatem wymienionym archiwaliom dokładniej. Zaświadczenie o zgonie wydane przez merostwo XIII dzielnicy jest bowiem nie tylko najcenniejszym (pośród prezentowanych tutaj) odnalezionym dokumentem, lecz także najbardziej naruszonym przez czas. Dokument ten, wystawiony na standardowym druku, poświadcza, że 23 V 1883 w domu przy ulicy Chevaleret 119 zmarł Cyprian Norwid. Potwierdza zarazem opłacenie podatku miejskiego i wykupienie koncesji na pochówek - dokument wystawiony 24 V 1883 na „p. Zaleskiego”, a dokładniej na Michała Zaleskiego, bliskiego przyjaciela i towarzysza ostatnich dni poety. To o nim i o poruszających okolicznościach odejścia Norwida w swoich listach z 23 V i 3 VI 1883 do syna Aleksandra tak pisał Józef Dybowski:

Zaczynam ten list doniesieniem Ci smutnej wiadomości, że Cyprian, który już od kilkunastu dni mocno na zdrowiu zapadł, wczoraj wieczorem rozstał się $z$ tym światem. Pogrzeb jego ma być pojutrze, w piątek, około 11-tej z rana. W ostatnich chwilach opiekował się nim i służył mu znany Ci Michał Zaleski, mój towarzysz broni z 1830; na jego rękach też skonał; bez niego byłby mu nikt w tej ostatniej chwili nie towarzyszył. Dzień dzisiejszy i jutrzejszy Zaleski oddaje wyłącznie usługom, z których najtrudniejsza jest obchodzić polskich panów, aby się zdobyli na poniesienie kosztów choć skromnego, ale przyzwoitego pogrzebu ${ }^{5}$.

Gdyby Zaleski nie zajął się był całym urządzeniem tego pogrzebu, nie poszedł do nieznajomych mu Jełowickiego i Kleczkowskiego, i wielu innych kroków nie poczynił, to Cyprian byłby pochowany, jak wszyscy inni weterani mieszkający w polskim Zakładzie rue de Chevaleret, w grobie zbiorowym (fosse comune) ${ }^{6}$.

Listy te stanowią doskonały komentarz i objaśnienie dla dokumentu z merostwa - czy może przeciwnie: to zaświadczenie potwierdza i poniekąd ilustruje słowa

$4 \quad$ Zob. ibidem.

5 J. Dybowski, list do A. Dybowskiego, z 23 V 1883. W: Z. Troja nowiczowa, E. Lijewska, Kalendarz życia i twórczości Cypriana Norwida (przy współudz. M. Pluty). T. 2: 1861-1883. Poznań 2007, s. 782.

6 J. Dybowski, list do A. Dybowskiego, z 3 VI 1883. W: jw., s. 783. 
Dybowskiego o kulisach nadchodzacych dni, o znaczacej roli, jaką odegrał Zaleski po śmierci przyjaciela, oraz o wysiłku włożonym w przygotowanie uroczystości pogrzebowych. Zaświadczenie pozytywnie weryfikuje także datę śmierci odnotowaną w akcie zgonu, ostatecznie zaprzeczając relacji Dybowskiego, jakoby Norwid zmarł 22, a nie $23 \mathrm{~V}$.

Na zamieszczonym dalej dokumencie, pośród wszystkich niezbędnych danych i informacji, dość enigmatycznie brzmi fraza: „Changement par substitution de classe”, przetłumaczona tutaj jako: „Zmienić poprzez podstawienie klasy”. W roku 1805 Nicolas Frochot, prefekt Sekwany i radca stanu, ustanowił zasadę opłaty pogrzebowej, w której skład wchodziła stała kwota podatku oraz prowizja pobierana od najwyższych klas orszaku pogrzebowego, wskazywanych przez arystokrację i burżuazję ${ }^{7}$. $Z$ oczywistych przyczyn w dokumencie $z$ merostwa nie wypełniono tej rubryki.

Pogrzeb Norwida odbył się $25 \mathrm{~V}$, według relacji Dybowskiego uczestniczyło w nim niewiele ponad 30 osób, głównie najbliżsi poety. Tak o pochówku na cmentarzu w Ivry pisała siostra Teofila Mikułowska w liście z 7 V 1883 do Michaliny Zaleskiej:

Pochowany jest [Norwid] na cmentarzu Ivry za miastem, za miastem, gdyż wszystkie inne cmentarze w Paryżu pozamykane, nie wolno więcej chować nikogo na nich. Był pochowany bardzo przyzwoicie, gdyż umiejący ocenić Go złożyli się na pogrzeb [... $]^{8}$.

\section{Podatek miejski / zaświadczenie o zgonie}

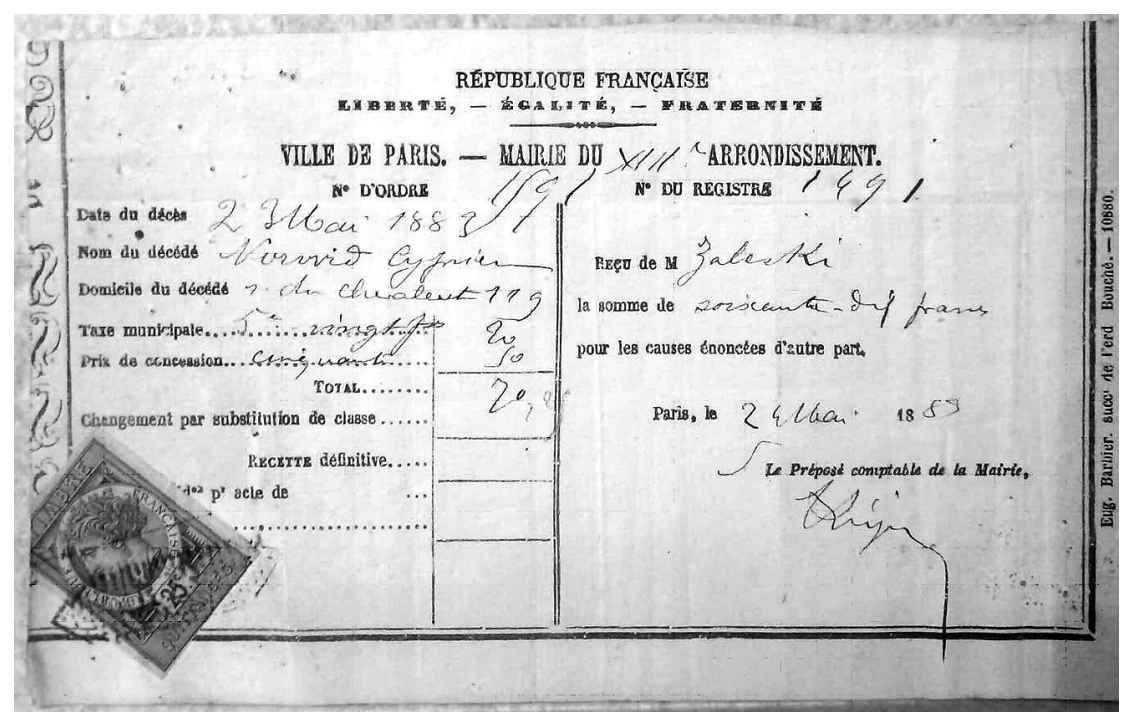

7 W Paryżu obowiązywało 11 klas orszaku pogrzebowego, z czego 3 należały do najdroższych. W wersji najokazalszej zasłaniano fasadę domu rodzinnego, wnętrze zamieniano w „kaplicę”, karawan zaś ozdabiano piórami lub kokardami. Zob. P. Trompette, R. H. Griffith s, L'Économie morale de la mort au XIXe siècle. Regards croisés sur la France et l’Angleterre. „Le Mouvement Social” 2011, nr 4.

8 Dybowski, list do Dybowskiego, z 3 VI 1883, s. 783. 
République Française

Liberté - égalité - fraternité

Ville de Paris - Mairie du XIII[éme $]^{9}$ arrondissement

$\mathrm{N}^{\circ}$ d'ordre $1591 \mathrm{~N}^{\circ}$ du registre 1491

Date du décès 23 Mai 1883

Nom du décédé Norwid Cyprian

Domicile du décédé $r$. de Chevaleret 119

Taxe municipale vingt francs 20

Prix de concession cinquante 50

Total 70

Changement par substitution de classe

Recette définitive

[...] p'acte de
Reçu de M Zaleski

la somme de soixante-dix francs

pour les causes énoncées d'autre part.

Paris le 24 Mai 1883

Le Préposé de comptable de la Mairie, [...]

\section{Republika Francuska \\ Wolność - równość - braterstwo \\ Miasto Paryż - Ratusz XIII dzielnicy \\ Numer zamówienia 1591 Numer rejestracyjny 1491}

Data śmierci 23 maja 1883

Nazwisko zmarłego Norwid Cyprian

Dom zmarłego ul. de Chevaleret 119

Podatek miejski dwadzieścia franków 20

Cena koncesji pięćdziesiąt 50

Razem 70

Zamiana poprzez podstawienie klasy

Przepis końcowy

[...] akt
Otrzymano od p. Zaleskiego

sumę siedemdziesięciu franków

za usługi wymienione obok.

Paryż 24 maja 1883

Księgowy Urzędu Miasta, [...]

W przywołanym już artykule Fert odnotował: „dotarłem [...] do dokumentacji przeniesienia Norwida $z$ cmentarza w Ivry na Montmorency" ${ }^{10}, \mathrm{w}$ istocie jednak badaczowi chodzi nie tyle o dokumentację w sensie ścisłym, ile o list Bolesława Rubacha do Stanisława Loewenhardta - obaj byli członkami Komisji Opieki nad Grobami Polskimi - oraz o dwie rękopiśmienne informacje: jedną o przeniesieniu prochów Norwida $z$ Ivry do Montmorency i drugą z listą dokumentów przekazanych Loewenhardtowi. Pod numerem czwartym owej listy znajduje się zaświadczenie omówione wcześniej (Reçu de la mairie du XIIIe arr[ondissemen]t). Numer trzeci $\mathrm{z}$ wykazu to z kolei Concession au cimetière. Jak podaje Zbigniew Sudolski, Zaleski wykupił na cmentarzu w Ivry koncesje jedynie na 5 lat, do 1888 roku $^{11}$. Gdy na posiedzeniu Komisji Opieki nad Grobami Władysław Mickiewicz dowiedział się o zbliżającym się terminie, doszło do szybkiej mobilizacji i dzięki pozyskanym funduszom zorganizowano ekshumację szczątków Norwida oraz przeniesienie ich do zbiorowego grobu na cmentarzu w Montmorency ${ }^{12}$. Na podstawie zachowanej korespondencji możemy dziś z cała pewnością uznać, że to dzięki Michalinie Dziekońskiej udało się sfinalizować ekshumację i ponowny pochówek poety ${ }^{13}$, a samą

Elementy dopisane odręcznie oznaczono w odczytaniu kursywą.

F e r t, op. cit., s. 134.

Z. S u dols ki, Norwid. Opowieść biograficzna. Warszawa 2003, s. 606.

Zob. Trojanowiczowa, Lijewska, op. cit., t. 2, s. 784 .

Zob. ibidem. 
organizacja i sprawami formalnymi zajęli się działacze komisji. Oto fragment listu Rubacha do Loewenhardta z 30 VII:

Szanowny Doktorze!

Dostałem na przeniesienie śp. Norwida 100 rs - wyraźnie: sto rubli - przeto zniesiona została przeszkoda materialna.

We środę przyszłą wyjeżdżam z Paryża; nie mogę się obecnie zająć tą sprawą, przeto - jeżeli Szanowny Doktor sądzi za stosowne - można by Plucińskiego i Norwida przenieść w krótkim czasie ${ }^{14}$.

Kolejne dwa odnalezione dokumenty stanowią efekt i dowód podjętych wówczas działań. Sa to rachunki za opłacenie podatku od ekshumacji oraz przeniesienia zwłok z cmentarza w Ivry (18 IV 1888) na cmentarz w Montmorency (27 IX 1888). W obu przypadkach przedsiębiorca pogrzebowym, który zajmował się tą sprawa, był Jacquet i to na niego zostały wystawione wspomniane dokumenty. Sporządzono je na standardowych urzędowych drukach, różniących się jedynie nieznacznie rejestrem świadczonych usług. Oba rachunki opiewają na kwoty 20 franków. Przed uroczystym przeniesieniem zwłok, które miało nastapić 28 XI 1888, Komisja Opieki nad Grobami rozpowszechniła następujące ogłoszenie:

We środę 28 listopada (1888), o 8-ej rano odbędzie się przeniesienie zwłok Cypriana Norwida z cmentarza Ivry do Montmorency, między 11-tą a 12-tą w cmentarzu Montmorency. Od rodziny i przyjaciół ${ }^{15}$.

„Cmentarz polski”, „panteon polskiej emigracji”, „największa polska nekropolia we Francji", to najczęstsze określenia, jakie można usłyszeć, gdy mowa o cmentarzu Champeaux położonym w niewielkiej, malowniczej miejscowości Montmorency, kilkanaście kilometrów na północ od Paryża. Tam w zbiorowej mogile, obok swojego przyjaciela Tomasza Olizarowskiego, na kilka następnych lat spoczął Norwid.

\section{Rachunek z cmentarza w Ivry}

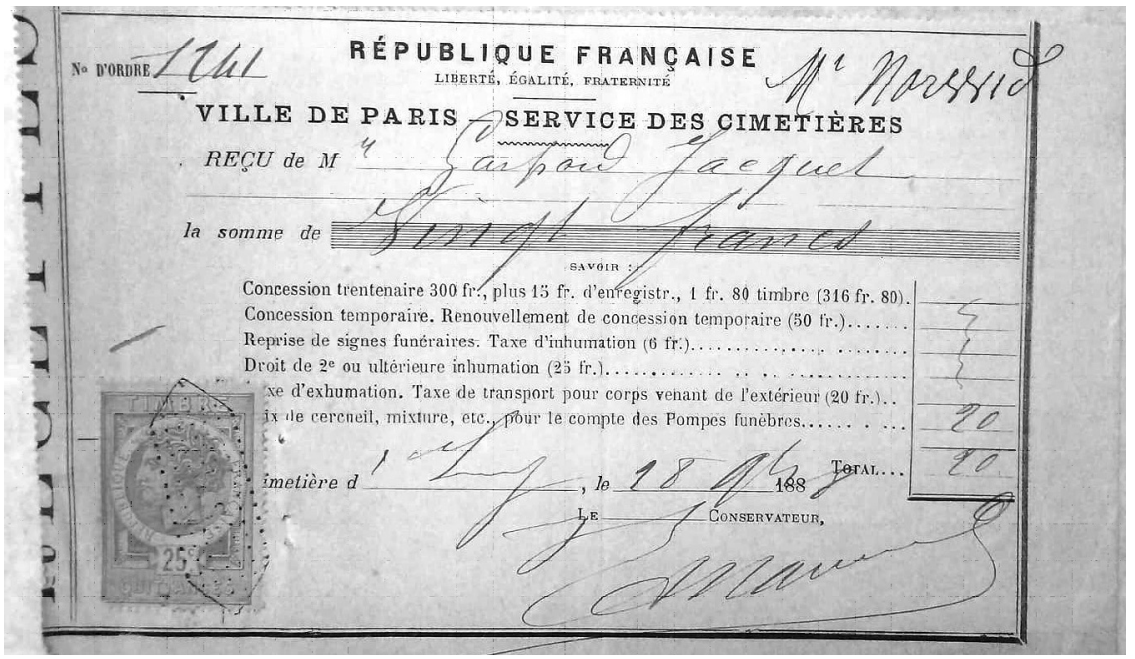

B. Ruba ch, list do S. Loewenhardta, z 30 VII 1883. Cyt. za: Fert, op. cit., s. 135. Sudolski, op. cit., s. 613. 
$\mathrm{N}^{\mathrm{o}}$ d'ordre 1141

République Française

M. Norwid

Liberté, égalité, fraternité

Ville de Paris - Service de cimetières

Reçu de M. Gaspard Jacquet

la somme de vingt francs

Savoir:

Concession trentenaire 300 fr., plus 15 fr. d'enregistr., 1 fr. 80 timbre (316 fr. 80).

Concession temporaire. Renouvellement de concession temporaire (50 fr.)

Reprise de signes funéraires. Taxe d'inhumation (6 fr.)

Droit de $2^{\mathrm{e}}$ ou ultérieure inhumation (25 fr.)

[Ta]xe d'exhumation. Taxe de transport pour corps venant de l'extérieur (20 fr.)

[Pr]ix de cercueil, mixture, etc., pour le compte des Pompes funébres

[C]imetière d'Ivry, le 18.04.1888

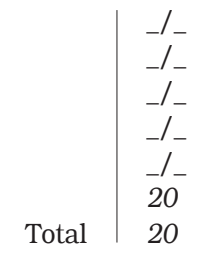

Le

Conservateur,

[...]

Nr zamówienia 1141

Republika Francuska

p. Norwid

Wolność, równość, braterstwo

Miasto Paryż - Wydział Cmentarzy

Otrzymano od p. Gasparda Jacqueta

suma dwudziestu franków

Informacja:

Trzydziestoletnia koncesja 300 fr., plus 15 fr. opłata rejestr., 1 fr. 80 znaczek (316 fr. 80).

Tymczasowa koncesja. Odnowienie tymczasowej koncesji (50 fr.)

Wznowienie opłat pogrzebowych. Podatek pogrzebowy (6 fr.)

Prawo do drugiego lub kolejnego pochówku (25 fr.)

Podatek od ekshumacji. Podatek transportowy dla organów pochodzących z zewnątrz (20 fr.)

[Ce]na trumny, mieszanka itp., w imieniu domów pogrzebowych

[C]mentarz w Ivry, dnia 18.04.1888

\begin{tabular}{l|l} 
& 20 \\
Razem & 20
\end{tabular}

konserwator,

\section{Rachunek z cmentarza w Montmorency}

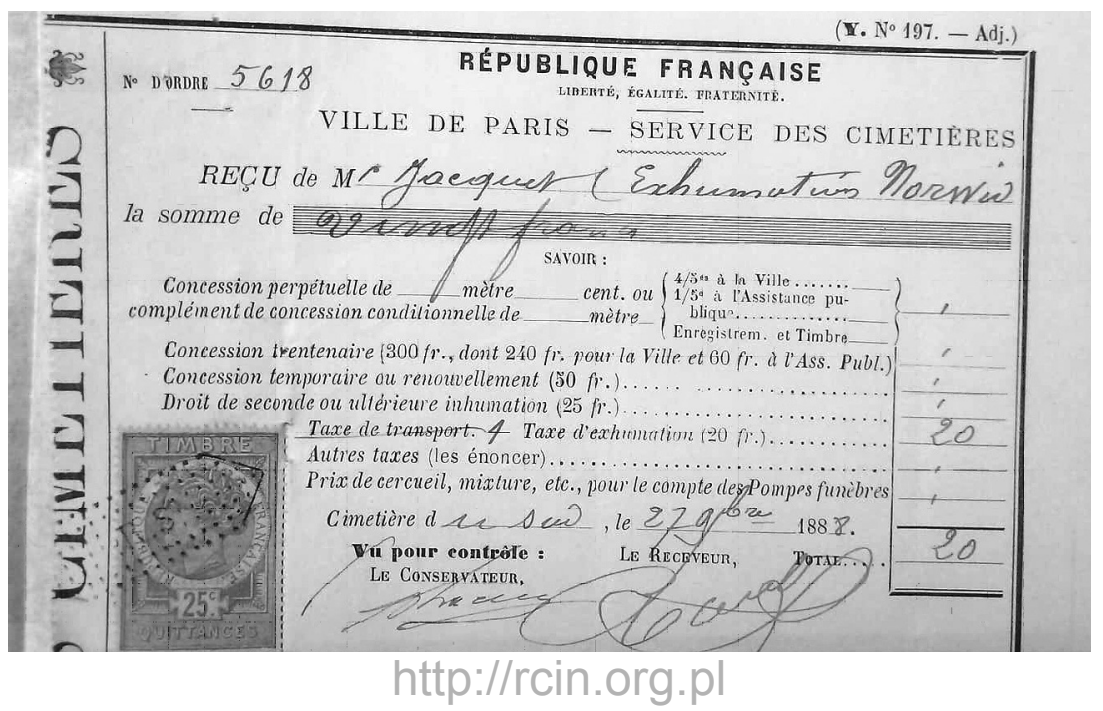


No d'ordre 5618

République Française

Liberté, égalité, fraternité

Ville de Paris - Service de cimetières

Reçu de M. Jacquet Exhumation Norwid

la somme de vingt francs

Savoir:

Concession perpétuelle de mètre ___ cent. ou complément de concession conditionnelle de mètre

$4 / 5^{\text {es }}$ à la Ville

$1 / 5^{\mathrm{e}}$ à l'Assistance publique Enregistrem. et Timbre

Concession trentenaire (300 fr., dont 240 fr. pour la Ville et 60 fr. à l'Ass. Publ.)

Concession temporaire ou renouvellement (50 fr.)

Droit de seconde ou ultérieure inhumation (25 fr.)

Faxe de transport. 4 Taxe d'exhumation (20 fr.)

Autres taxes (les énoncer)

Prix de cercueil, mixture, etc., pour le compte des Pompes funebrès

Cimetière du Sud, le $279^{\text {bre }} 1888$

Vu pour contrôle:

Le Conservateur,

[...]

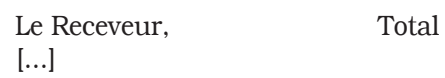

Nr zamówienia 5618
Republika Francuska

Wolność, równość, braterstwo

Miasto Paryż - Wydział Cmentarzy

Otrzymano od p. Jacqueta ekshumacja Norwida

suma dwudziestu franków

Informacja:

Wieczysta koncesja metr cm gdzie

dodatkowa koncesja warunkowa metr

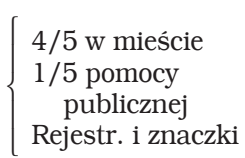

-

$-1$

$-1$

20

$-1$

-

20

Trzydziestoletnia koncesja (300 fr., z czego 240 fr. dla miasta i 60 fr. dla pomocy publicznej) Tymczasowa koncesja lub odnowienie (50 fr.)

Prawo do drugiego lub kolejnego pochówku (25 fr.)

Podatek transportowy. 4 Podatek od ekshumacji (20 fr.)

Inne podatki (stwierdzone)

Cena trumny, mieszanka itp., w imieniu domów pogrzebowych

Cmentarz Południowy, dnia 27 listopada 1888

Skontrolowano:

Konserwator, [...]

$$
\text { Odbiorca, Razem }
$$$$
\text { [...] }
$$

Jednym $z$ drugoplanowych bohaterów tej opowieści, choć mimowolnym i niezamierzonym, staje się Gaspard Jacquet, paryski przedsiębiorca pogrzebowy, który - jak można sądzić z prawie wszystkich zachowanych i prezentowanych tu dokumentów - współpracował z Komisją Opieki nad Grobami na stałe. Jego zakład mieścił się $u$ wylotu bulwaru Edgara Quineta pod numerem 54, w sąsiedztwie największej paryskiej nekropolii - cmentarza Montparnasse. Choć dziś po przedsiębiorstwie samego Jacqueta nie ma śladu, to w sassiedztwie słynnej nekropolii wciąż funkcjonują zakłady pogrzebowe i kamieniarskie. W odniesieniu do wieku XIX we Francji możemy mówić o powstaniu i rozwoju prawdziwego przemysłu 
pogrzebowego, w którym znaczącą rolę odgrywa właśnie przedsiębiorca pogrzebowy. Uważne przestudiowanie czterech kolejnych odnalezionych dokumentów bardzo dobrze pokazuje, jak szeroki zakres usług oferowano i wykonywano w owym czasie.

Wszystkie rachunki wystawiono na drukach firmy Jacqueta, wymiarami zbliżonych do formatu A4. Pierwszy z dokumentów, bez daty oraz nazwiska, dotyczy usług świadczonych w latach 1887-1889, w tym też dla Norwida. Obcą ręką nad pierwsza pozycja dodano: „Pour M. Rettel”. Najprawdopodobniej chodzi o Leonarda Rettla (1811-1885), pisarza i tłumacza, działacza emigracyjnego ${ }^{16}$, także mieszkańca paryskiego Zakładu św. Kazimierza. Można zatem założyć, że rachunek faktycznie powinien odnosić się do usług pogrzebowych wykonanych również w związku z pochówkiem pisarza w 1885 roku. Kolejne pozycje na rachunku dotyczą pogrzebów Ignacego Czernika (1803-1887), Euzebiusza Rydzewskiego (1841-1882, na rachunku data ponownego pochówku: 1887) i Kazimierza Gregorowicza (1833-1889). Przedostatnią pozycję, pod datą 2 X 1888, zajmuje Norwid.

\section{Rachunek od przedsiębiorcy pogrzebowego, Gasparda Jacqueta, bez daty}

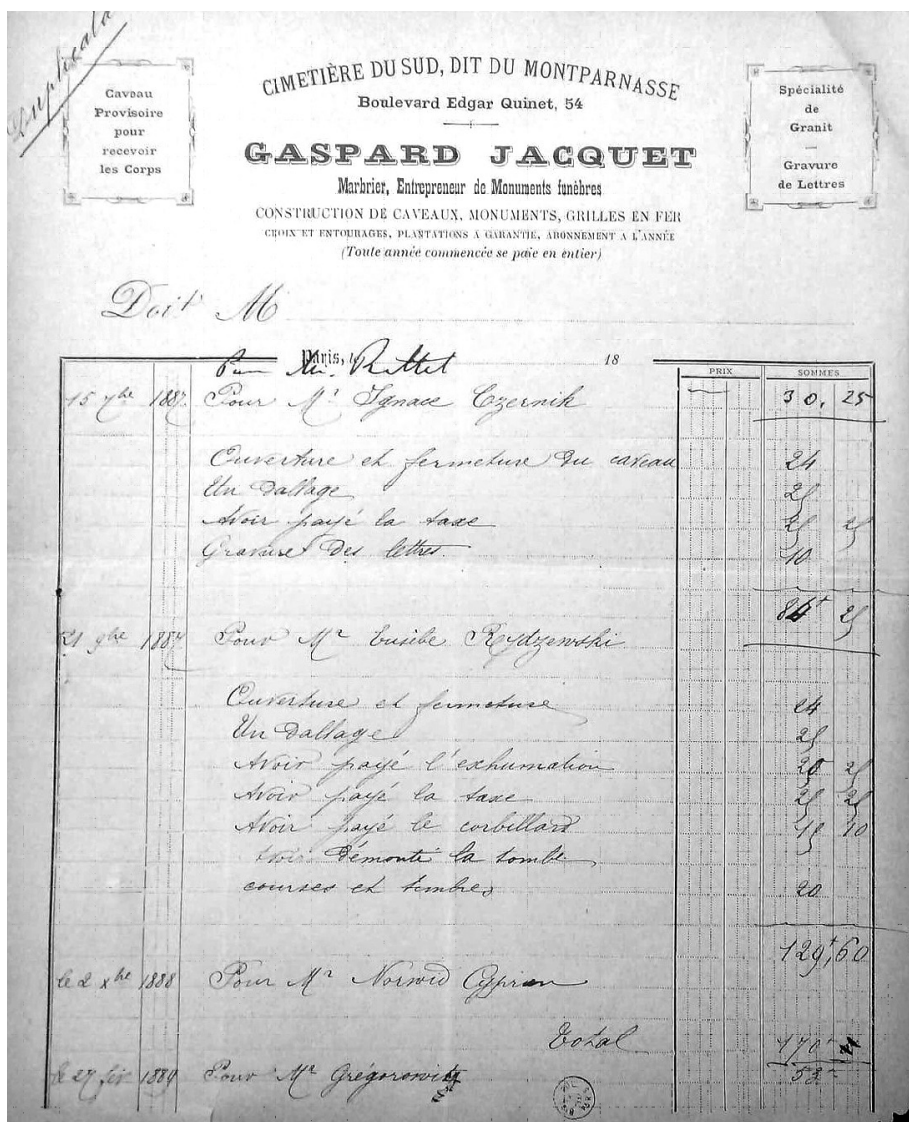


$\underline{\text { Duplicata }}$

\begin{tabular}{|c|}
\hline Caveau \\
Provisoire \\
pour \\
recevoir \\
les Corps \\
\hline
\end{tabular}

\section{CIMETIĖRE DU SUD, DIT DU MONTPARNASSE \\ Boulevard Edgar Quinet, 54 \\ GASPARD JACQUET}

Marbrier, Entrepreneur de Monuments funèbres CONSTRUCTION DE CAVEAU, MONUMENTS, GRILLES EN FER Croix et entourages, plantations à garantie, abonnement à l'année

(Tout année commencée se paie en entier)
Spécialité

de

Granit

Gravure

de Lettres

Doit M.

Paris, le $18 \ldots . .$.

Pour M. Rettel

\begin{tabular}{|c|c|c|c|c|c|}
\hline & & & prix & \multicolumn{2}{|c|}{ sommes } \\
\hline $157^{t e}$ & 1887 & $\begin{array}{l}\text { Pour M. Ignace Czernik } \\
\text { Ouverture et fermeture du caveau } \\
\text { Un dallage } \\
\text { Avoir payé la taxe } \\
\text { Gravure des lettres }\end{array}$ & & $\begin{array}{l}30, \\
24 \\
29 \\
29 \\
10\end{array}$ & $\begin{array}{l}25 \\
29\end{array}$ \\
\hline & & & & $84^{+}$ & 29 \\
\hline $219^{\text {bre }}$ & 1887 & $\begin{array}{l}\text { Pour M. Eusèbe Rydzewski } \\
\text { Ouverture et fermeture [du caveau] } \\
\text { Un dallage } \\
\text { Avoir payé l'exhumation } \\
\text { Avoir payé la taxe } \\
\text { Avoir payé le corbillard } \\
\text { Avoir démonté la tombe } \\
\text { Courses et timbres }\end{array}$ & & $\begin{array}{l}24 \\
29 \\
20 \\
29 \\
19 \\
\\
20\end{array}$ & $\begin{array}{l}29 \\
29 \\
10\end{array}$ \\
\hline & & & & 129, & +60 \\
\hline le $2 X^{\text {he }}$ & 1888 & Pour M. Norwid Cyprian & & & \\
\hline & & Total & & $170^{+}$ & \\
\hline le 27 fév. & 1889 & Pour M. Gregorowicz & & 53 & \\
\hline
\end{tabular}

Duplikat

Tymczasowy
grobowiec
na przyjęcie
ciała

CMENTARZ POŁUDNIOWY, ZNANY JAKO MONTPARNASSE

Bulwar Edgara Quineta 54

GASPARD JACQUET

Marmurarz, przedsiębiorca pomników pogrzebowych

KONSTRUKCJA PIWNIC, POMNIKI, SIATKI ŻELAZNE

Krzyże i otoczenie, plantacje gwarantowane, roczny abonament

(Za każdy zamówiony rok płaci się w całości)

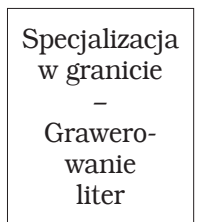

Należność p.

Paryż, dnia $18 \ldots . .$.

Dla p. Rettla

\begin{tabular}{|c|c|c|c|c|c|}
\hline & & & cena & \multicolumn{2}{|c|}{ suma } \\
\hline 15.07 & 1887 & $\begin{array}{l}\text { Dla p. Ignacego Czernika } \\
\text { Otwarcie i zamknięcie grobowca } \\
\text { Kostka brukowa } \\
\text { Opłacenie podatku } \\
\text { Grawerowanie liter }\end{array}$ & & $\begin{array}{l}30 \\
24 \\
29 \\
29 \\
10\end{array}$ & $\begin{array}{l}25 \\
29\end{array}$ \\
\hline & & & & $84^{+}$ & 29 \\
\hline 21.11 & 1887 & $\begin{array}{l}\text { Dla p. Euzebiusza Rydzewskiego } \\
\text { Otwarcie i zamknięcie [grobowca] } \\
\text { Kostka brukowa } \\
\text { Opłacenie ekshumacji } \\
\text { Opłacenie podatku }\end{array}$ & & $\begin{array}{l}24 \\
29 \\
20 \\
29\end{array}$ & $\begin{array}{l}29 \\
29\end{array}$ \\
\hline
\end{tabular}




\begin{tabular}{|l|l|l|c|c|c|} 
& & $\begin{array}{l}\text { Optacenie karawanu } \\
\text { Rozbiórka grobu } \\
\text { Kursy i znaczki }\end{array}$ & 19 & 10 \\
\hline & & & 20 & 129, & +60 \\
\hline dnia 2.10 & 1888 & Dla p. Norwida Cypriana & & & \\
\hline & & & & $170^{+}$ & \\
\hline dnia 27 lutego & 1889 & Dla p. Gregorowicza & & \\
\hline
\end{tabular}

Drugi $z$ omawianych rachunków został wystawiony 5 I 1889 na nazwisko wspominanego już Loewenhardta, polskiego lekarza i powstańca styczniowego, ale także znanego w kręgach emigracji w Paryżu działacza Komisji Opieki nad Grobami, zamieszkałego - według dokumentu - przy ulicy Montparnasse 44, czyli niewiele ponad 200 m od zakładu Jacqueta. Rachunek dotyczy jedynie ekshumacji i przeniesienia zwłok Norwida z Ivry do Montmorency i zawiera dokładne wyliczenie wraz ze stawkami każdej podjętej i wykonanej usługi. Trzeci $z$ kolei to duplikat, z 9 I 1891, podsumowujący niejako wydatki poniesione i jeszcze nieopłacone przez Komisję w ciagu kilku lat. Oprócz nazwiska Norwida znajdziemy tam także - poza nowymi - po raz kolejny Czernika, Rydzewskiego czy Gregorowicza.

\section{Rachunek od przedsiębiorcy pogrzebowego, Gasparda Jacqueta, z 5 I 1889}

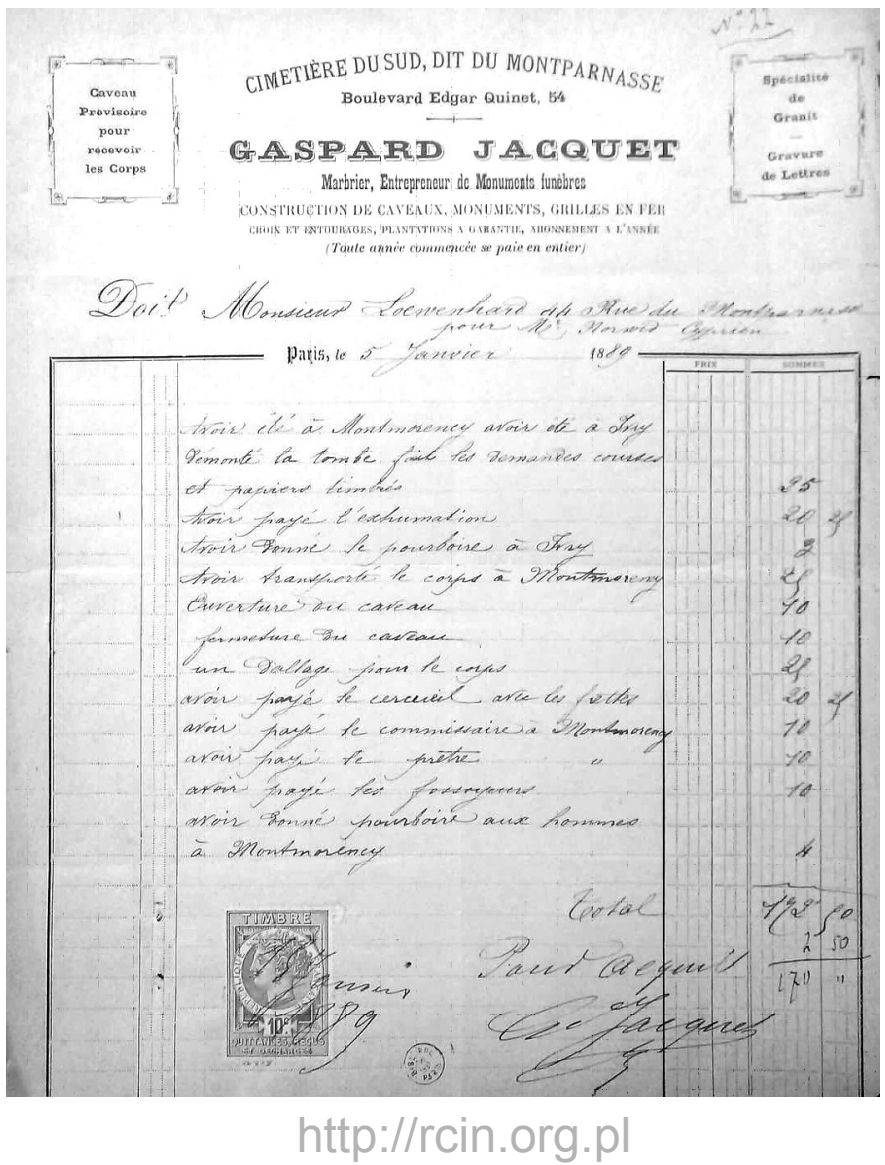


Caveau

Provisoire pour recevoir les Corps
CIMETIĖRE DU SUD, DIT DU MONTPARNASSE

Boulevard Edgar Quinet, 54

GASPARD JACQUET

Marbrier, Entrepreneur de Monuments funèbres CONSTRUCTION DE CAVEAU, MONUMENTS, GRILLES EN FER Croix et entourages, plantations à garantie, abonnement à l'année (Tout année commencée se paie en entier)
Spécialité de

Granit

Gravure de Lettres

Doit Monsieur Loewenhard 44 Rue du Montparnasse pour M. Norwid Cyprien Paris, le 5 Janvier 1889

\begin{tabular}{|c|c|c|c|}
\hline & prix & \multicolumn{2}{|c|}{ sommes } \\
\hline $\begin{array}{l}\text { Avoir été à Montmorency avoir été á Ivry } \\
\text { démonté la tombe fait les demandes courses } \\
\text { et papiers timbrés } \\
\text { Avoir payé l'exhumation } \\
\text { Avoir donné le pourboire à Ivry } \\
\text { Avoir transporté le corps à Montmorency } \\
\text { Ouverture du caveau } \\
\text { Fermeture du caveau } \\
\text { un dallage pour le corps } \\
\text { avoir payé le cerceuil avec les frettes } \\
\text { avoir payé le commissaire à Montmorency } \\
\text { avoir payé le pretre } \\
\text { avoir payé le fossoyeurs } \\
\text { avoir donné le pourboire aux hommes } \\
\text { à Montmorency }\end{array}$ & & $\begin{array}{r}25 \\
20 \\
3 \\
29 \\
10 \\
10 \\
29 \\
20 \\
10 \\
10 \\
10\end{array}$ & 29 \\
\hline Total & & 172 & 90 \\
\hline & & 2 & 50 \\
\hline & & $17^{\prime \prime}$ & \\
\hline Pour acquit & & & \\
\hline Gaspard Jacquet & & & \\
\hline
\end{tabular}

Tymczasowy grobowiec na przyjęcie ciała

\section{CMENTARZ POŁUDNIOWY, ZNANY JAKO MONTPARNASSE} bulwar Edgara Quineta 54 GASPARD JACQUET

Marmurarz, przedsiębiorca pomników pogrzebowych KONSTRUKCJA PIWNIC, POMNIKI, SIATKI ŻELAZNE Krzyże i otoczenie, plantacje gwarantowane, roczny abonament (Za każdy zamówiony rok płaci się w całości)
Specjalizacja

w granicie

$-$

Grawero-

wanie

liter

Należność pana Loewenhardta, ulica Montparnasse 44, dla p. Norwida Cypriana Paryż, dnia 5 stycznia 1889

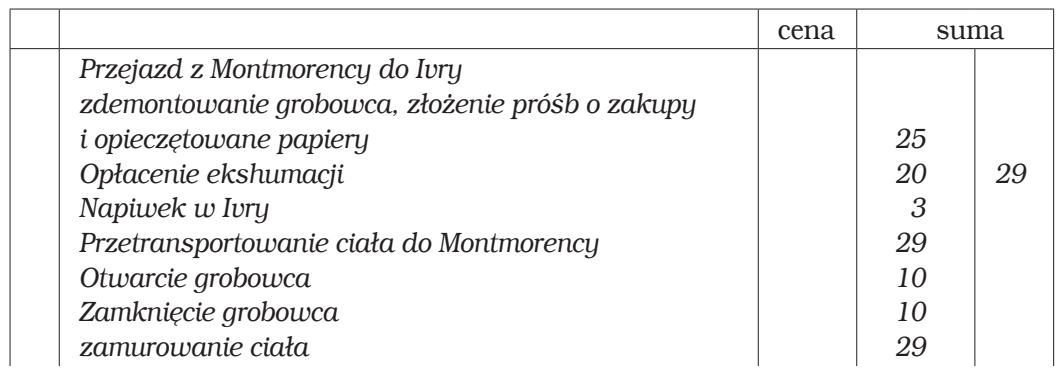




\begin{tabular}{|c|c|c|c|}
\hline \multicolumn{2}{|c|}{$\begin{array}{l}\text { opłacenie trumny z okuciami } \\
\text { opłacenie komisarza Montmorency } \\
\text { opłacenie księdza } \\
\text { opłacenie grabarzy } \\
\text { napiwek dla mężczyzn } \\
\text { z Montmorency }\end{array}$} & $\begin{array}{l}20 \\
10 \\
10 \\
10\end{array}$ & 29 \\
\hline \multirow{3}{*}{\multicolumn{2}{|c|}{ Razem }} & 172 & 90 \\
\hline & & 2 & 50 \\
\hline & & $17^{\prime \prime}$ & $"$ \\
\hline \multicolumn{4}{|c|}{ Zapłacono } \\
\hline 14 stycznia 1889 & Gaspard Jacquet & & \\
\hline
\end{tabular}

\section{Rachunek od przedsiębiorcy pogrzebowego, Gasparda Jacqueta, z 9 I 1891}

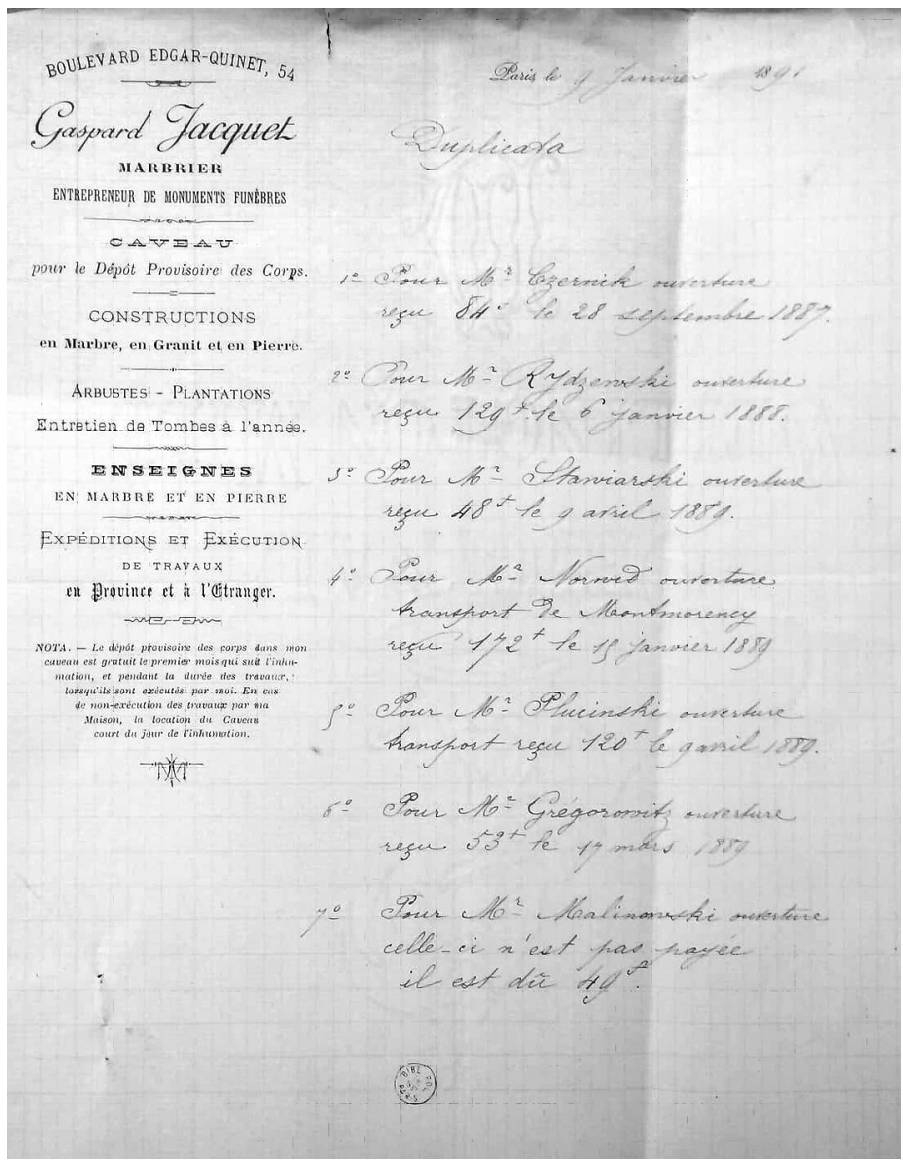


Boulevard Edgar-Quinet, 54

GASPARD JACQUET Marbier

Duplicata

Paris, le 9 Janvier 1891

Entrepreneur de Monuments funèbres

CAVEAU

pour le Dépôt Provisoire des Corps

CONSTRUCTIONS

en Marbre, en Granit et en Pierre

ARBUSTES - PLANTATIONS

Entretien de Tombes à l'année

ENSEIGNES

en Marbre et en Pierre

\section{EXPÉDITIONS ET EXÉCUTION \\ DE TRAVAUX \\ en Province et à l'Étranger}

NOTA. - Le dépôt provisoire des corps dans mon caveau est gratuit le premier mois qui suit l'inhumation, et pendant la durée des travaux, lorsqu'ils sont exécutés par moi. En cas de non-exécution des travaux par ma Maison, la location de Caveau court du jour de l'inhumation.

\section{Bulwar Edgara Quineta 54 GASPARD JACQUET} Marmurarz

Przedsiębiorca pomników pogrzebowych

GROBOWIEC

na tymczasowe przechowanie ciał

KONSTRUKCJE

w marmurze, granicie i kamieniu

KRZEWY - PLANTACJE

Coroczna konserwacja grobowców

SZYLDY

w marmurze i kamieniu

\section{EKSPEDYCJA I WYKONANIE PRAC}

na prowincji i za granica

NOTA. - Tymczasowy depozyt ciał w moim grobowcu jest bezpłatny przez pierwszy miesiąc po pogrzebie i przez czas pracy, kiedy sa one wykonywane przeze mnie.

W przypadku niewykonywania prac przez mój Dom wynajem piwnicy rozpoczyna się w dniu pochówku. $1^{\circ}$ Pour M. Czernik ouverture reçu 84 f. le 28 septembre 1887

$2^{\circ}$ Pour M. Rydzewski ouverture reçu 129 f. le 6 janvier 1888

$3^{\circ}$ Pour M. Stawiarski ouverture reçu $48 \mathrm{f}$. le 9 avril 1889

$4^{\circ}$ Pour M. Norwid ouverture transport de Montmorency reçu 172 f. le 19 janvier 1889

$5^{\circ}$ Pour M. Plucinski ouverture transport reçu $120 \mathrm{f}$. le 9 avril 1889

$6^{\circ}$ Pour M. Gregorovitz ouverture reçu 53 f. le 17 mars 1889

$7^{\circ}$ Pour M. Malinowski ouverture celle-ci n'est pas payée il est dû $49 \mathrm{f}$.

Duplikat

Paryż, 9 stycznia 1891

1. Dla p. Czernika otwarcie, otrzymano $84 \mathrm{f}$. dnia 28 września 1887

2. Dla p. Rydzewskiego otwarcie, otrzymano 129 f. dnia 6 stycznia 1888

3. Dla p. Stawiarskiego otwarcie, otrzymano 48 f. dnia 9 kwietnia 1889

4. Dla p. Norwida otwarcie, transport do Montmorency, otrzymano 172 f. dnia 19 stycznia 1889

5. Dla p. Plucińskiego otwarcie, transport, otrzymano $120 \mathrm{f}$. dnia 9 kwietnia 1889

6. Dla p. Gregorowicza otwarcie, otrzymano $53 \mathrm{f}$. dnia 17 marca 1889

7. Dla p. Malinowskiego otwarcie, nie opłacono, należy zapłacić $49 \mathrm{f}$. 
Ostatnie $\mathrm{z}$ prezentowanych archiwaliów to także rachunek $\mathrm{z}$ przedsiębiorstwa Jacqueta, nie dotyczy on jednak pochówku Norwida, ale Juliusza Słowackiego. Dokument został wystawiony w listopadzie 1894 na nazwisko Loewenhardta za usługi renowacyjne wykonane 4 maja. Wydaje się, że historia nagrobka Słowackiego, wzniesionego dzięki staraniom jego matki, jest powszechnie znana. Początkowy projekt miał stworzyć zaprzyjaźniony z poetą rzeźbiarz Charles Petiniaud, ostatecznie skromny pomnik został ozdobiony medalionem wykonanym przez Władysława Oleszczyńskiego, jednego z najwybitniejszych polskich rzeźbiarzy okresu romanty$\mathrm{zmu}^{17}$. Znajdujący się obecnie na nagrobku medalion jest kopią z 1894 roku, prawdopodobnie wymieniono go właśnie podczas renowacji przeprowadzonej przez Jacqueta.

\section{Rachunek od przedsiębiorcy pogrzebowego, Gasparda Jacqueta, z listopada 1894}

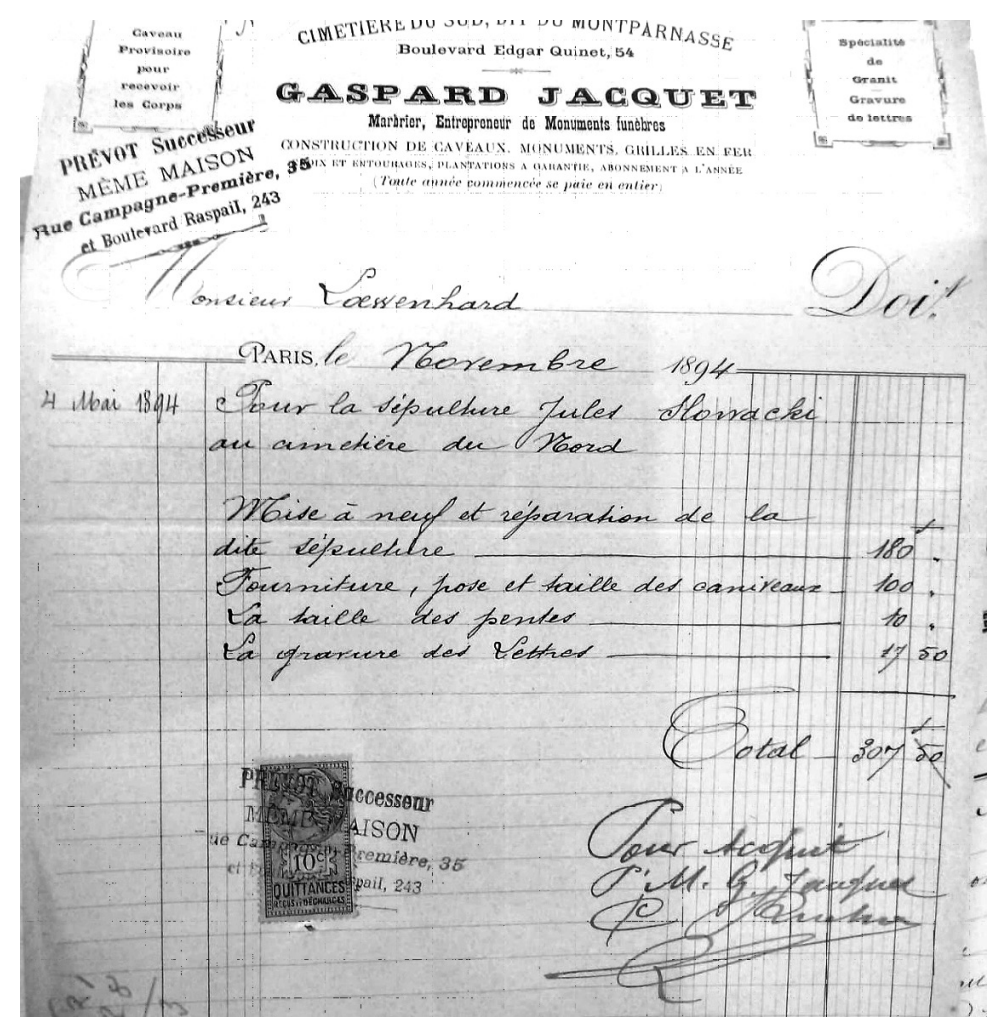

17 Zob. A. Pi eń k o s, Paryż, nagrobek Juliusza Stowackiego (Paris, tombeau de Jules Slowacki). Na stronie: http://www.polonika.gov.pl/pages/pl/polonik.php?id=41\&name=paryz-nagrobek-juliusza-slowackiego (data dostępu: 27 III 2020). 


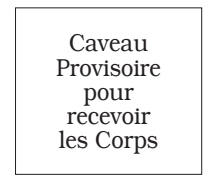

PRÉVOT Successeu MÈME MAISON

Rue Campagne-Première, 35

et Boulevard Raspail, 243
CIMETIÈRE DE SUD, DIT DU MONTPARNASSE

Boulevard Edgar Quinet, 54

GASPARD JACQUET

Marbrier, Entrepreneur de Monuments funèbres CONSTRUCTION DE CAVEAU, MONUMENTS, GRILLES EN FER

Croix et entourages, plantations à garantie, abonnement à l'année

(Tout année commencée se paie en entier)

Monsieur Loewenhard Doit

Paris, le Novembre 1894

\begin{tabular}{|c|c|c|c|}
\hline \multirow[t]{2}{*}{4 Mai 1894} & $\begin{array}{l}\text { Pour la sépulture Jules Slowacki } \\
\text { au cimetière du Nord } \\
\text { Mise à neuf et réparation de la } \\
\text { dite sépulture } \\
\text { Fourniture, pose et taille des caniveaux } \\
\text { La taille des pentes } \\
\text { La gravure des Lettres }\end{array}$ & $\begin{array}{r}180 \\
100 \\
10 \\
17 \\
\end{array}$ & 50 \\
\hline & Total & 307 & 50 \\
\hline
\end{tabular}

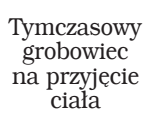

Tymczasowy grobowiec na przyjęcie ciała

CMENTARZ POEUDNIOWY, ZNANY JAKO MONTPARNASSE

Bulwar Edgara Quineta 54

GASPARD JACQUET

Marmurarz, przedsiębiorca pomników pogrzebowych

KONSTRUKCJA PIWNIC, POMNIKI, SIATKI ŻELAZNE

Krzyże i otoczenie, gwarantowane plantacje, roczny abonament

STARSZY Następca

TEGO ZAKŁADU

Ulica Campagne-Première 35

i bulwar Raspail 243

(Za każdy zamówiony rok płaci się w całości)

Pana Loewenhardta. Należność
Spécialité de Granit Gravure de Lettres

\begin{tabular}{|c|c|c|c|}
\hline \multicolumn{4}{|c|}{ Paryż, listopad 1894} \\
\hline 4 maja 1894 & $\begin{array}{l}\text { Za złożenie do grobu Juliusza Słowackiego } \\
\text { na Cmentarzu Pótnocnym } \\
\text { Remont i naprawa } \\
\text { rzeczonego grobu } \\
\text { Dostawa, instalacja i dopasowanie rynien } \\
\text { Dopasowanie spadków } \\
\text { Grawerowanie liter }\end{array}$ & $\begin{array}{r}180 \\
100 \\
10 \\
17 \\
\end{array}$ & 50 \\
\hline & Razem & 307 & 50 \\
\hline & $\begin{array}{c}\text { STARSZY Nastepca } \\
\text { TEGO ZAKŁADU } \\
\text { Ulica Campagne-Première } 35 \\
\text { i bulwar Raspail } 243\end{array}$ & $\begin{array}{r}Z \\
\text { P. M. G. } \\
{[\ldots]}\end{array}$ & $\begin{array}{l}\text { icono } \\
\text { cquet } \\
\text { chery }\end{array}$ \\
\hline
\end{tabular}

Zbiór paryskich norwidianów „rozpoczyna” dokument z 1883 roku, „kończy” zaś rachunek z 1891 roku. Od tego czasu upłynie jeszcze 5 lat, zanim Gomulicki ogłosi w krakowskim „Przeglądzie Literackim”, iż pracuje nad monografią poświęcona poecie, i minie kolejny rok, zanim Zenon Przesmycki odkryje Norwida. O Słowackim nigdy nie zapomniano, choć i jego twórczość dopiero na przełomie XIX i XX wieku doczekała się uznania. W roku 1927 jego prochy zostały uroczyście 
złożone na Wawelu, ziemia z grobu Norwida dopiero w 2001 roku trafiła do krypty poetów.

Prezentację zbioru archiwaliów rozpoczęto od przywołania historii Komisji Opieki nad Grobami, instytucji, która niezmiennie od niemal 180 lat opiekuje się polskimi miejscami pochówku w Paryżu. Aby zatem domknąc ramę kompozycyjną, przedstawiamy ostatnie znalezisko: bilet na loterię - jeden z licznych sposobów pozyskiwania środków na renowację grobów i organizację pogrzebów emigrantów.

\section{Bilet na Loterię Artystyczną Komisji Grobów Polskich}

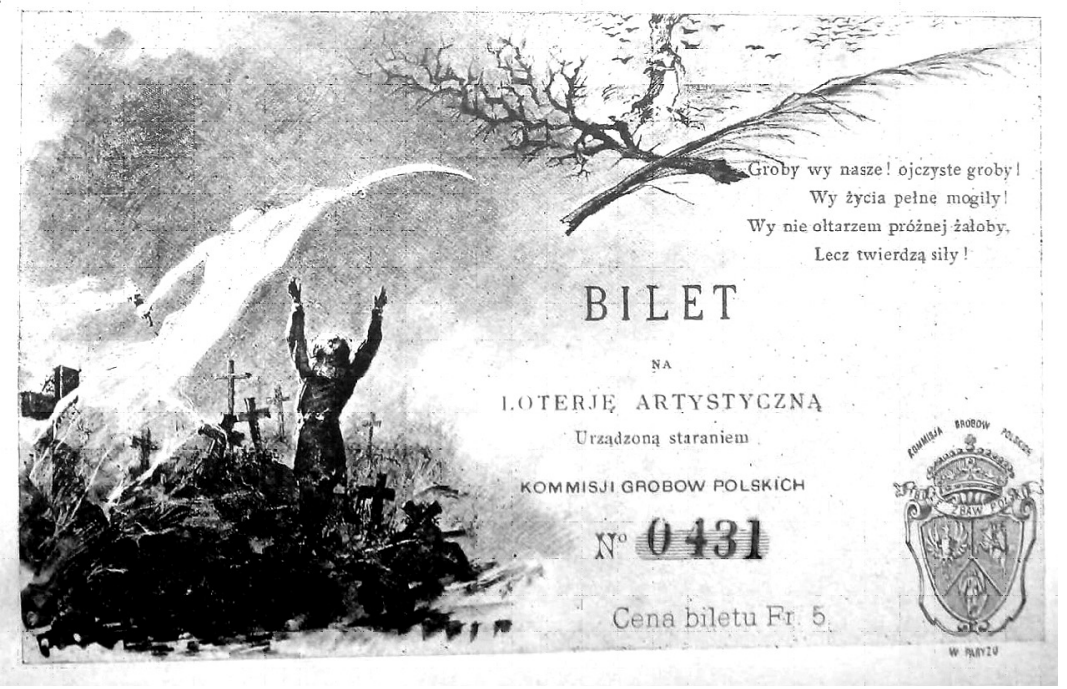

Abstract

MAGDALENA ABRAMCZYK Institute of Literary Research of the Polish Academy of Sciences, Warsaw

ORCID: 0000-0002-0213-1317

\section{NORWID IN THE POLISH LIBRARY IN PARIS}

The paper discusses the documents found while completing the tasks within the framework of a research project (no. 0514/NPRH/Hla/83/2015) in Alojzy Władysław Strzembosz's output preparation in the Polish Library in Paris. The documents refer to Cyprian Norwid's death and the issues linked to his funeral and exhumation. They include, inter alia, the poet's death certificate dated May $24^{\text {th }}, 1883$, issued by the $13^{\text {th }}$ arrondissement's Mayor's office, the Ivry Cemetery's exhumation bill issued April $18^{\text {th }}, 1888$, and a bill for transferring his corpse to the Montmorency Cemetery, dated September $27^{\text {th }}$, 1888. Among the discovered archive papers one also finds those that pertain to the activities of the Komisja Opieki nad Grobami Polskimi (Society for the Protection of Polish Graves) (now Towarzystwo Opieki nad Polskimi Zabytkami i Grobami Historycznymi we Francji 〈Society for the Protection of Polish Monuments and Historical Graves in France)) that started in France towards the end of 1830s. The article discusses and describes the discoveries, as well as their significance for the present day knowledge in the poet's posthumous fortune and for the activities of the Polish émigrés in Paris for the protection of Polish graves. 